\title{
Monumental Structures and Volcanic Activities: Excavating the Campana at San Andrés in the Zapotitán Valley, El Salvador
}

\begin{abstract}
Akira Ichikawa
This article presents stratigraphic data and radiocarbon dates combined with Bayesian modeling from San Andrés in the Zapotitán Valley, El Salvador, focusing on the Campana Structure, the largest and longest-used monumental structure at the site. These data refine the regional chronology of the valley and provide insights into the emergence, development, and abandonment of this pivotal center in southeastern Mesoamerica and its potential links to three related volcanic eruptions: Ilopango, Loma Caldera, and El Boquerón. These distinct volcanic events had pronounced effects on local people who innovated new monumental construction projects and used new volcanic debris as construction material after major eruptions. It is suggested that these monumental public building projects played an important role in the post-disaster recovery of societies by helping foster a sense of corporate identity. The use of volcanic material in constructions at San Andrés and the building of these massive structures may also have helped keep these events alive in the communal memory.
\end{abstract}

Keywords: monumental structure, volcanic activities, radiocarbon dates, Bayesian analysis, San Andrés

Este artículo presenta los datos estratigráficos y fechas de radiocarbono con estadísticas Bayesianas del sitio arqueológico San Andrés en el Valle de Zapotitán, El Salvador, enfocándose en La Campana, la cual es la estructura monumental más grande del sitio. Estos datos brindan información sobre el surgimiento, desarrollo y abandono de este centro fundamental en el sureste de Mesoamérica y sus vínculos potenciales con tres erupciones volcánicas: Ilopango, Loma Caldera y El Boquerón. Estos eventos volcánicos tuvieron efectos pronunciados en los pueblos prehispánicos que innovaron en nuevos proyectos de construcción monumentales y utilizaron nuevos materiales volcánicos como material de construcción después de las erupciones. Lo anterior sugiere que los proyectos de construcción monumentales y públicos tuvieron un papel importante en la recuperación de las sociedades después de los desastres, ya que ayudaron a fortalecer una identidad corporativa. El uso de materiales volcánicos en las construcciones y dichas estructuras masivas, también pueden haber formado parte de la memoria colectiva de los pobladores del valle, en la época prehispánica.

Palabres claves: estructuras monumentales, actividades volcánicas, fechas de radiocarbono, análisis bayesiano, San Andrés

$\mathrm{V}$ olcanism is one of the most studied hazardous events in archaeology; one reason is that volcanic products make this phenomenon relatively easy to recognize. Such events cause unpredictable and catastrophic damage to human societies (e.g., Balmuth et al. 2005; Cooper and Sheets 2012; Grattan and Torrence 2007; Oliver-Smith and Hoffman 1999). However, some recent studies show that volcanic disasters may also be seen as social rather than environmental phenomena (e.g., Grattan and
Torrence 2007:2; Torrence 2019). Sociocultural responses to hazardous events and the subsequent recovery processes vary considerably over time and space, and such responses to abrupt environmental changes remain a challenging research topic (Kintigh et al. 2014:18). Recent social-science-based research has tended to emphasize the need to avoid overly sensationalistic interpretations of the catastrophic impact of volcanic events (Grattan 2006; Grattan and Torrence 2007), because the scale of eruptions

Akira Ichikawa (Akira.Ichikawa@ colorado.edu) — Department of Anthropology, University of Colorado Boulder, 1350 Pleasant St., 233 UCB, Boulder, Colorado 80309, USA

Latin American Antiquity 33(1), 2022, pp. 135-154

Copyright (C) The Author(s), 2021. Published by Cambridge University Press on behalf of the Society for American Archaeology. This is an Open Access article, distributed under the terms of the Creative Commons Attribution licence (http://creativecommons.org/licenses/by/4.0/), which permits unrestricted re-use, distribution, and reproduction in any medium, provided the original work is properly cited.

doi:10.1017/laq.2021.28 
is not always proportional to their negative impacts on human societies (Sheets 2012).

Volcanic events tend to be prime movers of sociocultural changes (Hoffman 1999; OliverSmith 1996; Torrence 2019). The first-century AD eruption of Popocatepetl in Mexico triggered a large-scale movement of refugees in the Basin of Mexico, contributing to the development of large cities such as Teotihuacan, with its impressive monumental architecture (Plunket and Uruñuela 2005). This indicates that disasters compellingly motivate social actions, creating new power relations and leaders (Torrence 2019:260). Furthermore, volcanos or mountains become part of the human landscape, shaping the worldview of religions, belief systems, and communal memory in both past and present (Scarth 1999). For instance, in Mesoamerica, pyramids were artificial sacred mountains (Fash and López Luján 2009; Freidel et al. 1993) that were closely intertwined with diverse entities like peoples, deities, ancestors, natural worlds, and forces (Joyce 2020; Plunket and Uruñuela 2008). It is challenging to investigate such perceptions, embedded as they are in oral history, religion, cosmology, and the knowledge of what to do after the sudden occurrence of such hazardous events (Sheets 2016:154). Additionally, novel forms of construction or agricultural techniques may be invented as a consequence of social responses or the adaptation to new landscapes created by volcanic eruptions (Chester et al. 2005).

In research on social responses to volcanic eruptions, detailed studies - using a long-term perspective - of individual environmental settings where multiple volcanic events have occurred have recently gained importance (Torrence 2019:263). These provide insightful data that are challenging assumptions regarding human-volcanic interactions, such as the decision to stay or seek refuge elsewhere, who reoccupied post-eruption vacant landscapes, the development of a sense of place, relocation of agricultural land and living space, and food procurement in devasted areas (Chester et al. 2005:102-103; Sheets 2016:153-154; Torrence 2019:262-263). The Zapotitán Valley in El Salvador is an ideal place to study such phenomena because of its proximity to several volcanic events (Ferrés et al. 2011; Miller 2002; Sheets 2004,
2008; Sofield 2004), and Sheets and colleagues have already undertaken significant research on eruptions that affected this area (Sheets 2004, 2009, 2012; Sheets et al. 2015) - yet even such relatively recent studies tend to emphasize the physical characteristics of eruptions and their negative impacts, overlooking human creativity. Notably, however, recent advances in archaeological dating techniques and Bayesian analyses provide opportunities to refine local carbon dating chronologies and establish more accurately the timing of eruptions and subsequent post-eruption recovery processes.

This study aims to understand the interaction of volcanic disasters with the rise, development, and decline of San Andrés in El Salvador's Zapotitán Valley, one of the most important primary centers in southeastern Mesoamerica. It seeks to refine the local site chronology in relation to volcanic events by analyzing new excavations from monumental contexts and radiometric dating data obtained by the author at San Andrés from 2015 to 2019 . The results suggest that monumental building projects played an important role in the recovery process after all three volcanic events. The participation of local populations in monumental building projects, using volcanic products as construction material, may have been a means of reconstituting group identities after the disaster and of producing durable monuments that anchored the memories of these disasters in local identities at San Andrés.

\section{Volcanic Activities and the Zapotitán Valley}

The Zapotitán Valley is located in central El Salvador between the Santa Ana and San Salvador volcanic complexes and is surrounded by other small volcanoes (Figure 1). These volcanoes have an active history over the last 36,000 years (Ferrés et al. 2011; Sofield 2004), with three major volcanic events from the prehispanic period geologically identified and dated: the Tierra Blanca Joven (TBJ), Loma Caldera (LC), and El Boquerón (EB) eruptions. Detailed descriptions of the deposits and isopach maps showing the distribution of eruptive products from these eruptions are available in other studies (e.g., Dull et al. 2019; Ferrés et al. 2011; Miller 2002; Pedrazzi et al. 2019; Sofield 2004). 


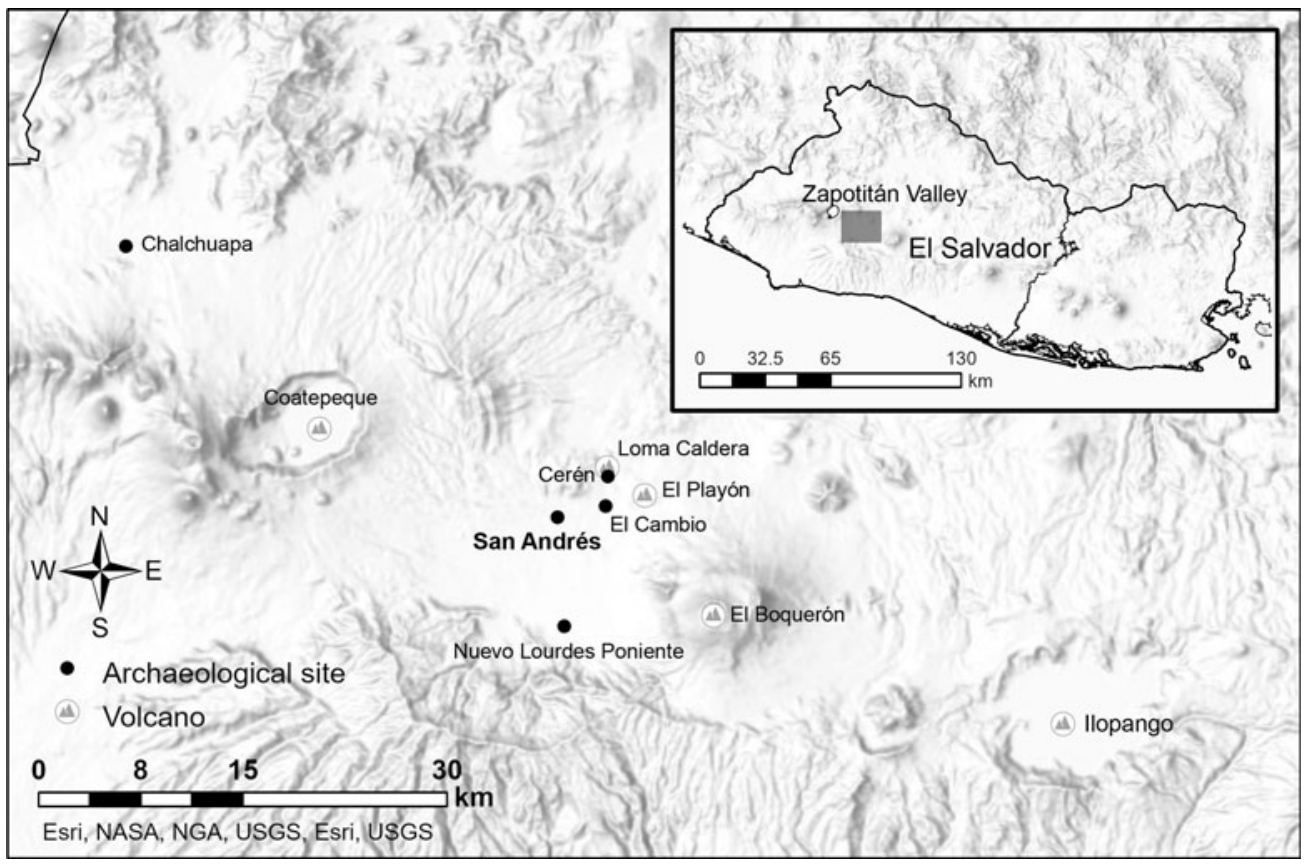

Figure 1. Map of the Zapotitán Valley, El Salvador.

\section{Tierra Blanca Joven Eruption}

The TBJ eruption, from the Ilopango caldera, is the largest known volcanic eruption in the Americas (Dull et al. 2001, 2019; Pedrazzi et al. 2019; Smith et al. 2020), with a volcanic explosivity index (VEI) of 6+ (Dull et al. 2019). Recent research has provided competing dates for the eruption, including AD 431 (Smith et al. 2020) and AD 539-540 (Dull et al. 2019). One reason for the difficulty in precisely determining the TBJ eruption date is that the dates fall within a plateau on the ${ }^{14} \mathrm{C}$ calibration curve, between AD 420 and 540 (1600-1550 yr BP).

The TBJ event had a devastating impact on western El Salvador and also affected more distant regions. Tephra deposits greater than $35 \mathrm{~cm}$ from the eruption covered an area of more than 20,000 km² (Dull et al. 2019:8). Combining the findings from previous and more recent excavations carried out by the author and others (Begley et al. 1997; Boggs 1943; McKee 2007), the TBJ tephra in San Andrés ranges from a depth of 0 to $52 \mathrm{~cm}$ and is divided into four units according to the definition of Dull and colleagues (2019). Unit II is the basal unit composed of pumice lapilli (or unit B; Pedrazzi et al. 2019); unit III (or unit D; Pedrazzi et al. 2019) comprises a lower pyroclastic surge succession (IIIa) and an upper ash fallout succession (IIIb); unit V (or unit E; Pedrazzi et al. 2019) is a double pumicelapilli fallout; and unit VII (unit G; Pedrazzi et al. 2019) is a white vitric ash layer recognized across El Salvador. A pyroclastic flow deposit, which had a deadly impact on human lives elsewhere, has not been recorded in the valley.

Dull and colleagues (2019:12) argued that the TBJ eruption forced the abandonment of many sites in western-central El Salvador, with the reoccupation of major sites with monumental architecture only occurring in the mid-seventh century. Additionally, Sheets (2004, 2008, 2009) suggested that Cerén was the first site occupied after the TBJ eruption in the Zapotitán Valley and, based on the similarities of cultural components, was not founded by pre-eruption villagers' direct descendants but instead was colonized by Maya immigrants from the Copan Valley. In contrast, Smith and colleagues (2020:6) argued that local to regional impacts appear to have been restricted to areas within a few hundred kilometers of the vent, meaning the effect of the eruption would have been significantly less drastic on a regional scale. 


\section{Loma Caldera Eruption}

The Loma Caldera (LC) is $600 \mathrm{~m}$ north of the Cerén site and $5 \mathrm{~km}$ north of San Andrés. The LC eruption magnitude was VEI 2, and its deposit covered areas within $6 \mathrm{~km}$ of the Loma Caldera crater (Miller 2002:14-15). The Cerén site radiocarbon data indicate a probable date for the LC eruption ranging between $\mathrm{AD} 610$ and 671 (95\% probability; McKee 2002:8). The well-studied LC tephra is divided into 14 units (Miller 2002), and its thickness as recorded in San Andrés is approximately $25 \mathrm{~cm}$ or less. According to Miller (2002), two units are identified in San Andrés; the lower part is unit 3, an indurated, laminated, and grayishbrown ash layer, and the upper part, unit 4 , is black scoria lapilli. The eruption's magnitude was smaller than the TBJ eruption, covering just a few square kilometers, but more than $5 \mathrm{~m}$ of volcanic deposits completely buried Cerén (Sheets 1983, 2002, 2008). Based on the stratigraphy of El Cambio site's, $2 \mathrm{~km}$ south of Cerén, human reoccupation occurred soon after this eruption (Sheets 2008:79). However, the regional impact of the LC eruptions remains unclear.

\section{El Boquerón Eruption}

The El Boquerón volcano (EB) forms part of the San Salvador volcanic complex, and its eruption magnitude was VEI 3. Based on the radiocarbon dating of a tree trunk buried by the eruption, Ferrés and others (2011:842) dated the EB eruption to AD 964-1040 (95\% probability), and its volcanic deposits cover a range of 200-300 $\mathrm{km}^{2}$ (Ferrés et al. 2011:843; Sofield 2004:151). The eruption's volcanic product is known locally as "San Andrés Talpetate Tuff" (Sofield 2004:151), a term used to describe indurated volcanic tuff (Ferrés et al. 2011:841). To clarify its correspondence with the eruption, this study uses the term "El Boquerón (EB) tephra." The EB tephra is widely recorded in the Zapotitán Valley and is roughly $10-150 \mathrm{~cm}$ thick depending on the distance from the vent. It is made up of two units (Ferrés et al. 2011:842-843): one is a dark-gray, well-sorted, normally graded, vesicular lapilli deposit, and the other is composed of multicolored, very fine ash layers at the base with abundant traces of plants. The latter unit was widely recorded in the valley and may have affected agricultural activities, being compact and hardened (Sheets 2004:116). It was around $10-30 \mathrm{~cm}$ thick in San Andrés. Excavation of San Andrés Mound B suggests that San Andrés's reoccupation occurred several decades after the eruption because a $5 \mathrm{~cm}$ thick layer of sedimentary soil was recorded between the EB tephra and the base of Mound B (Card 1997:53). However, the timing and impact of the EB eruptions have not yet been determined because of the lack of radiocarbon dates and archaeological data.

\section{Human History of Zapotitán Valley}

Based on the ceramic samples found at San Andrés (Begley et al. 1997), the early occupation of the Zapotitán Valley can be traced back to at least the Middle Preclassic period (1000-400 BC). In the Late and Terminal Preclassic (400 BC-AD 250), several sites spread out on the valley's flood plain; El Cambio-with an earthen mound that was $12 \mathrm{~m}$ high and four low mounds - was a possible Preclassic ceremonial center in the valley (Chandler 1983). In addition, previous studies reported extensive agricultural fields at San Andrés, Nuevo Lourdes Poniente, and other small sites (McKee 2007; Shibata and Herrera 2019). Regional ceramics shared traits with Chalchuapa and other southern Mesoamerican sites, such as Izalco Usulután decoration modes and nubbin/conical supports (Begley et al. 1997).

It is difficult to determine the characteristics and extent of occupation during the Early Classic period (AD 250-600) because of uncertainty regarding the TBJ eruption date and a lack of unequivocable occupation evidence. However, several ceramic groups corresponding to the Early Classic period; Guazapa, Chilanga, and Huiscoyol ceramic groups in the VEC phase in Sharer (1978) have been reported under and above the TBJ tephra in San Andrés and nearby sites in the Zapotitán Valley (Begley et al. 1997; Yagi et al. 2015). These findings suggest that researchers should pay more attention to the context before and after the TBJ eruption while researching its date and impact. In the following 
sections, this article provides new data relevant to this obscure period.

By the Late Classic period (AD 600-900/ 1000), large numbers populated the valley; based on settlement patterns, the valley's total population at this time is estimated at 40,000 100,000 (Black 1983:82). San Andrés became the political, economic, and religious center of the region, covering more than $3 \mathrm{~km}^{2}$. Its core comprises the Acropolis; the North (or Great) Plaza; four rectangular mounds measuring 30$50 \mathrm{~m}$ in length, $10-15 \mathrm{~m}$ in width, and $3 \mathrm{~m}$ high (possibly elite residences); and the largest monumental structure in the valley known as the "Campana Structure" (Structure 5, as shown in Figure 2). The core area was surrounded by a commoner residential area (McKee 2007). Monumental public buildings were made of adobe and mud plaster, except for Structure 7, which was built of large cut-stone blocks. Previous scholars link San Andrés to the Maya site of Copan based on its layout and an impressive cache that included a highly elaborate eccentric flint, a stingray spine, Spondylus shells, and Copador Polychrome vessels (Begley et al. 1997; Boggs 1943; Dimick 1941; McKee 2007; Mejia 1984). Although the settlement survey recorded other Late Classic sites in the valley (Black 1983), only Cerén, a commoner village entirely buried by the LC eruption, has been investigated in detail (Sheets 1983, 2000, 2002; Sheets et al. 2015). It has been assumed that Cerén commoners attended special ceremonies at San Andrés and obtained exotic items from far away, such as obsidian, jade, and Copador Polychrome vessels, through participation in a broad economic network (Sheets 2000; Sheets et al. 2015). The use of volcanic material at Ceren has also been pointed out: the sacbe ("white road" in Yucatec Mayan) was built with material from the TBJ eruption (Sheets et al. 2015:355). However, relations between San Andrés and Cerén remain unclear because of the lack of investigation at San Andrés.

During the Early Postclassic period (AD 900/ 1000-1200), the valley's population is estimated at 38,000-90,000 (Black 1983:82). San Andrés may still have been the primary center in the valley but was likely influenced by Pipil migrants from Central Mexico (Black 1983:89). Local architectural materials and techniques drastically changed, from earthen materials to the use of cut volcanic tuff blocks (Begley et al. 1997). In addition, Mixteca-Puebla-style ceramics, locally known as Bandera Polychrome, have been reported for this period (Begley et al. 1997; Camacho and Díaz 2015). The EB eruption occurred between AD 964 and 1040 (Ferrés et al. 2011:842). However, the causal link or links, if any exist, between the Pipil migration, changes in materials and techniques, and the EB eruption are still unknown.

As described previously, prolonged and consecutive human activities have been recorded in the volcanically active Zapotitán Valley. However, we do not yet understand when and how social complexity arose in the region, when San Andrés became the primary regional center, or about the process of its development and collapse. Furthermore, how these events relate to the aforementioned periodic volcanic events is unclear. To fill these gaps, this study presents new data clarifying our understanding of the architectural sequences, construction techniques, and radiocarbon dating at San Andrés, focusing on the largest monumental structure known as the Campana and its surroundings. These results challenge the previous understanding of the site's history and of relationships between human and volcanic activities in the valley.

\section{Excavating and Dating San Andrés}

\section{Datasets}

This article examines two datasets: (1) excavation data from the Campana Structure and its surrounding area at San Andrés carried out by the author and his colleagues during 2015-2019 and (2) new and existing Zapotitán Valley radiocarbon assays. Given that the Acropolis was already extensively excavated and reconstructed (Amaroli 2015; Boggs 1943; Dimick 1941), our excavations focused on the Campana Structure, a pyramidal structure atop a large basal platform. The platform measures approximately $85 \times 65 \mathrm{~m}$ and is $7 \mathrm{~m}$ high in its final form, and the pyramidal structure measures approximately $35 \times 40 \mathrm{~m}$ and is $13 \mathrm{~m}$ in height (Figures 2 and 3). Previous excavations of the Campana Structure carried 


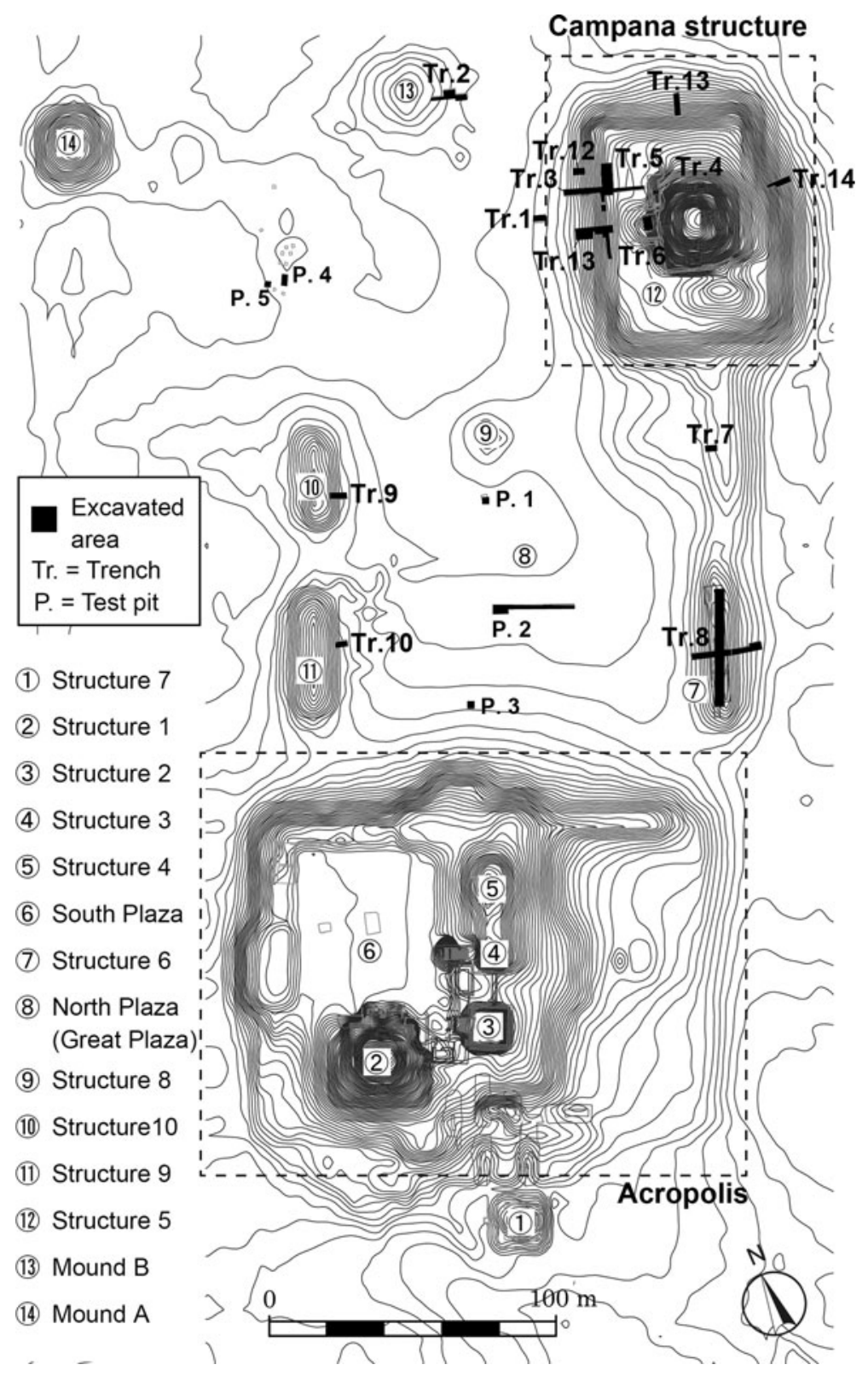

Figure 2. Plan of San Andrés showing structures and excavated areas.

out by Begley and colleagues (1997) focused on the pyramidal structures and the south half of the platform's west face. However, its dimensions, forms, and architectural sequences, especially in relation to its initial construction, remain unclear. To fully reveal the structure's construction history, excavations were carried out in 2015-2019 on the centerline and north half of the west face, as well as on the north and east faces of the platform. Four rectangular structures and the North Plaza, areas never before investigated, were excavated to better understand the site's development; other open areas were also investigated to determine early occupation. The on-mound excavation units were $2 \times 4 \mathrm{~m}$ long and, if necessary, were extended to better understand architectural features or sequences. Offmound units, especially on the North Plaza and 


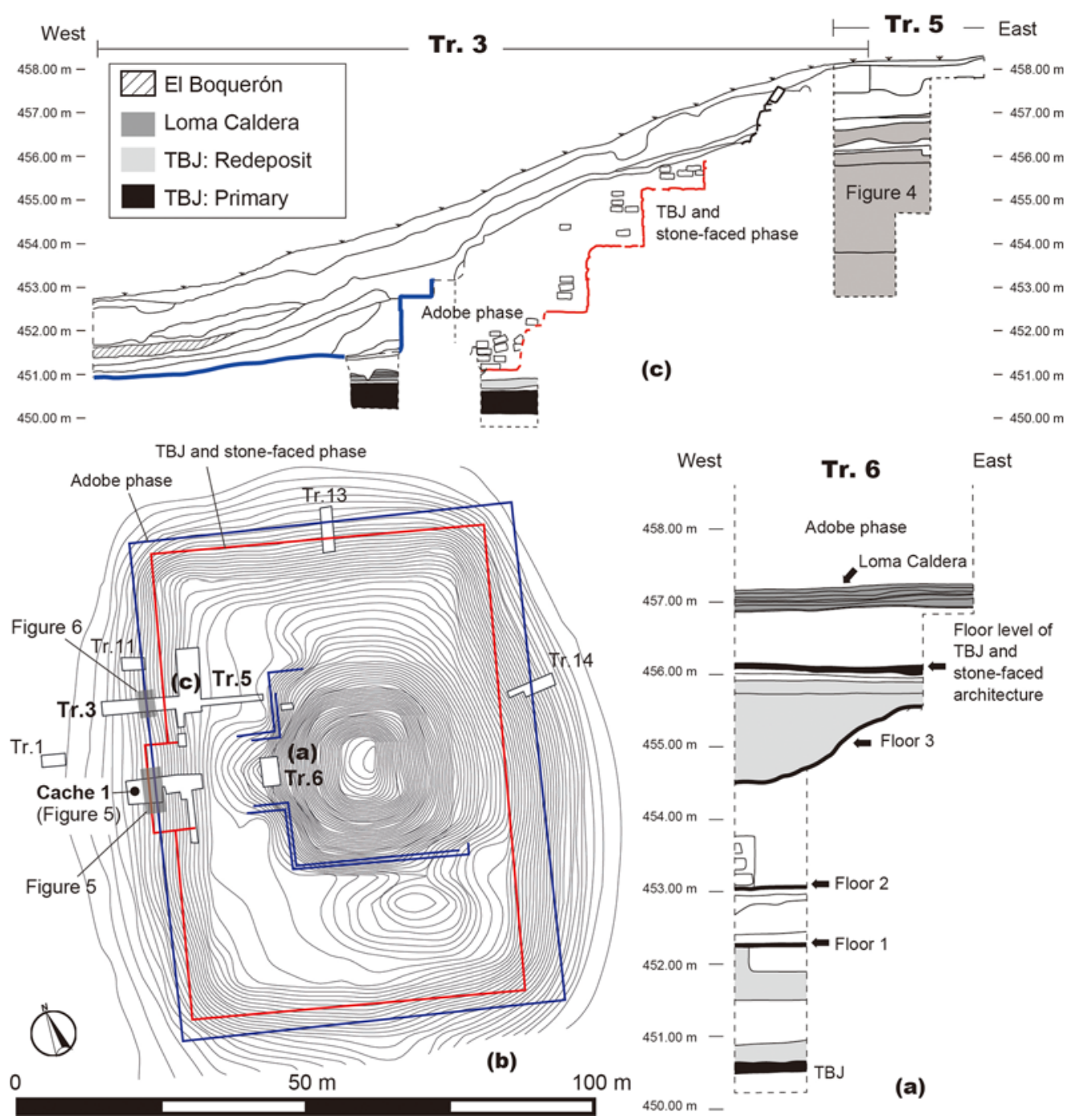

Figure 3. Plan and sections of the Campana Structure (Structure 5): (a) north section of Tr.6, (b) plan of the Campana Structure, and (c) north sections of Tr.3 and Tr.5.

open areas, were $2 \times 2 \mathrm{~m}$ long and extended as needed. They were excavated at arbitrary $20 \mathrm{~cm}$ levels unless cultural features or stratigraphic changes were detected. In total, excavations uncovered an area of $631 \mathrm{~m}^{2}$ and 1-8 $\mathrm{m}$ deep depending on the unit: they included eight excavation units on the Campana Structure, 10 in the North Plaza, and four on low rectangular mounds surrounding the North Plaza (Figure 2). The stratigraphic and architectural sequences of the Campana Structure and other structures are shown in Supplemental Figure 1.
The other dataset consists of 27 radiocarbon dates from the Campana Structure and other public buildings in San Andrés (Supplemental Table 1). Sixteen charcoal samples from the Campana Structure came from different construction phases: the TBJ and earth phase, the TBJ and stone-faced phase, and the adobe phase. Another six charcoal samples came from Structure 6, a rectangular adobe structure on the North Plaza built above the LC tephra and renovated at least twice. Structures 9 and 10, two additional adobe superstructures built on the North Plaza above the LC tephra, each 
provided one charcoal sample. Finally, two samples came from the context under the TBJ, and one sample was recovered in the Late Classic bell-shaped pit uncovered near Mound B. All samples were run using accelerator mass spectrometry (AMS) radiocarbon techniques at the Laboratory of Radiocarbon Dating at the University of Tokyo Museum, Japan.

Also included in this analysis were four additional radiocarbon dates for samples recovered from burned middens located in a residential area (McKee 2007:285, 296). Two were found beneath the EB tephra, and the other two were beneath approximately $10-20 \mathrm{~cm}$ thick volcanic deposits called the talpetate inferior, possibly from an eruption of the San Salvador volcano complex, probably Los Chintos (McKee 2007:50). However, considering other geological and vulcanological studies in the Zapotitán Valley (Ferrés et al. 2011; Miller 2002; Sofield 2004) and the stratigraphic location between the TBJ and EB tephra, this layer could be the LC tephra. As seen in Supplemental Table 1, the calibrated dates of A-12580 and A-12581 are AD 425-650 (95\% probability), supporting this assumption.

Additionally, this study includes and reexamines previous radiocarbon assays to assess the regional chronology (Supplemental Table 2). Eight Cerén samples and two from El Cambio were analyzed (McKee 2002:7; Sheets 1983:7; Slotten 2015:72). Given that the LC eruption entirely buried Cerén, the dating of these samples is near the eruption date. The El Cambio samples are from the test pits but were stratigraphically located between the LC and EB tephra (Chandler 1983:111). Three human skeletal remains from Nuevo Lourdes Poniente were also included in this study (Ichikawa et al. 2014): these three burials were associated with the Late Classic polychrome vessels (Gualpopa and Arambala group in Sharer [1978]) found at the site. Finally, four samples associated with the EB tephra were included. These samples are carbonized tree trunks recovered $2.5 \mathrm{~km}$ north of the $\mathrm{El}$ Boquerón crater (Ferrés et al. 2011:842). Calibration of the radiocarbon dates was carried out using OxCal v.4.4.2 and the IntCal20 calibration curve (Bronk Ramsey 2020; Reimer et al. 2020).

This study uses Bayesian statistics to refine the chronology and the estimated construction phase dates in relation to volcanic activities. To this end, identifying problematic samples is important because contaminated materials, such as old wooden materials or materials from old contexts (e.g., Inomata et al. 2014), are often introduced at sites with long and successive occupations. Considering the stratigraphy, associated ceramic types, and quality of the samples (especially their ${ }^{13} \mathrm{C}$ value) and of the dated materials, an inconsistent date known as an "outlier" can be identified before Bayesian modeling is conducted. This process identified samples TKA-17789, 17794, 17795, 17797, and 19377 as outliers. Human remains from Nuevo Lourdes Poniente have low ${ }^{13} \mathrm{C}$ values, suggesting these samples could be problematic. However, stratigraphic data, calibrated dates, and associated ceramics are consistent, making them suitable for the Bayesian model.

Bayesian analysis with OxCal can also identify problematic dates through the statistical likelihoods of outliers called "agreement indices," which need to be $60 \%$ or higher for the agreement to be considered good (Bronk Ramsey 2009:1025). The analysis identified TKA17793, 19376, 19381, and 21284 as outliers and reached the most plausible model by incorporating stratigraphic information and archaeological materials. Owing to the uncertainty of the TBJ eruption date, this study used AD $420-540$ as the uniform distribution in the model, meaning that the event could have occurred at any point within this time period with equal probability (Bronk Ramsey 2009:1026). For the LC eruption, Cerén's dates were combined into the model (McKee 2002; Sheets 1983; Slotten 2015). However, only two samples used current AMS dating techniques (A-10743 and AA105791). Because the conventional age ranges for other Cerén data tend to be large due to the limitations of the technology available at that time, those with ranges of \pm 100 years above (ELS-40 and TX3120) are excluded from the model. To calculate the EB eruption date, data provided by Ferrés and colleagues (2011) were included.

\section{Stratigraphic and Architectural Sequence}

Excavations reveal more evidence of Preclassic period occupation than previously thought 
(Black 1983:88). The amount (around 30\% of the ceramic sample) and variations of ceramic types in the Late and Terminal Preclassic period suggest a significant presence. Yet, despite this significant evidence of Late and Terminal Preclassic occupations (e.g., Begley et al. 1997; McKee 2007), excavations have not found Late and Terminal Preclassic monumental architecture in San Andrés; it was likely a village during this time. Preliminary ceramic analysis suggests that during the early part of the Early Classic, before the TBJ eruption, activities at San Andrés may have declined, as indicated by a small quantity of ceramic types from this period.

Subsequently, the Zapotitán Valley was entirely covered by a large amount of TBJ tephra (Ferrés et al. 2011; Dull et al. 2019). Excavations in different areas at San Andrés confirmed that the primary TBJ tephra's thickness varied and was as high as $52 \mathrm{~cm}$ and that the tephra directly covered the agricultural fields (McKee 2007). According to the TBJ tephra definition (Dull et al. 2019), units II, III, V, and VII were recorded in San Andrés.

Excavation data indicate that the first monumental public building at San Andrés was constructed after the TBJ eruption and that it was established directly on primary TBJ tephra. Stratigraphic data in Trench 6 show this structure was built with TBJ tephra redeposits and earth (Figures 3a and 4). The builders first mixed different units of tephra from the TBJ deposit and then deposited and compacted these soils as construction fill. Variable TBJ tephra thicknesses at the site suggest that builders may have intentionally extracted the TBJ tephra from surrounding areas and redeposited it to construct this monumental public building. Another earthen structural fill material was yellowish-brown or brown, clayey, and compacted. The TBJ tephraearth phase of the Campana Structure was renovated at least three times, finally reaching $6 \mathrm{~m}$ in height. The floors, approximately $5 \mathrm{~cm}$ thick, were composed of dark-brown clay with pumice inclusions. Because of the limited excavation, the form and volume of the TBJ-earth phase architecture remain unclear. Ceramics of the Chilanga and Machacal groups, corresponding to the Early Classic period (Sharer 1978), were recovered from the construction fill, although in low quantities.
The subsequent building was constructed of an approximately $5 \mathrm{~m}$ thick TBJ redeposit faced by cut-stone blocks (Figures 3b, 3c, and 5). The TBJ redeposit had slightly different compositions (Figure 4). For instance, one area consists of only unit VII, whereas another one mixes units II and VII, suggesting the presence of different primary TBJ tephra units. Only four small, scraped slip potsherds (Guazapa group) were recovered from the TBJ redeposit, suggesting that the TBJ redeposit was carefully mixed, deposited, and compacted. The cut-stone blocks included volcanic tuffs and slabs. Their sizes varied $(20-70 \mathrm{~cm}$ length, $20-50 \mathrm{~cm}$ width, and $10-20 \mathrm{~cm}$ height), their form was irregular, and cut-stone blocks were placed directly on the TBJ construction fill. These materials are available from the eastern slope of the San Salvador volcanic complex, although further exploration is needed to verify whether this actually was the source. The TBJ and stone-faced phase architecture were used to build a platform measuring approximately $80 \times 55 \mathrm{~m}$ and $6 \mathrm{~m}$ high (Figure 3b). Based on the architectural features, the platform's volume is at least $24,000 \mathrm{~m}^{3}$, accounting for approximately $75 \%$ of the Campana Structure's volume. The platform had four terraces and a central staircase on its west side that is $16 \mathrm{~m}$ wide (Figures $3 \mathrm{~b}, 3 \mathrm{c}$, and 6).

Notably, the TBJ and stone-faced construction described in the previous paragraph is located under the LC tephra. The primary LC tephra recorded in the Campana Structure was approximately $25 \mathrm{~cm}$ thick. According to the Cerén sequence (Miller 2002:21), these units correspond to units 3 and 4 . This stratigraphic relation indicates that the TBJ and stone-faced phase of the Campana Structure must have been contemporaneous with Cerén. Excavation data from elsewhere at San Andrés have as yet failed to uncover other monumental structures dating to the period between the TBJ and LC eruptions.

After the LC eruption, a large-scale monumental public construction project was initiated at San Andrés. Architectural materials, techniques, styles, and probably labor organization substantially changed. Buildings were constructed using adobe bricks and mud plaster (except for Structure 7, which was made of 


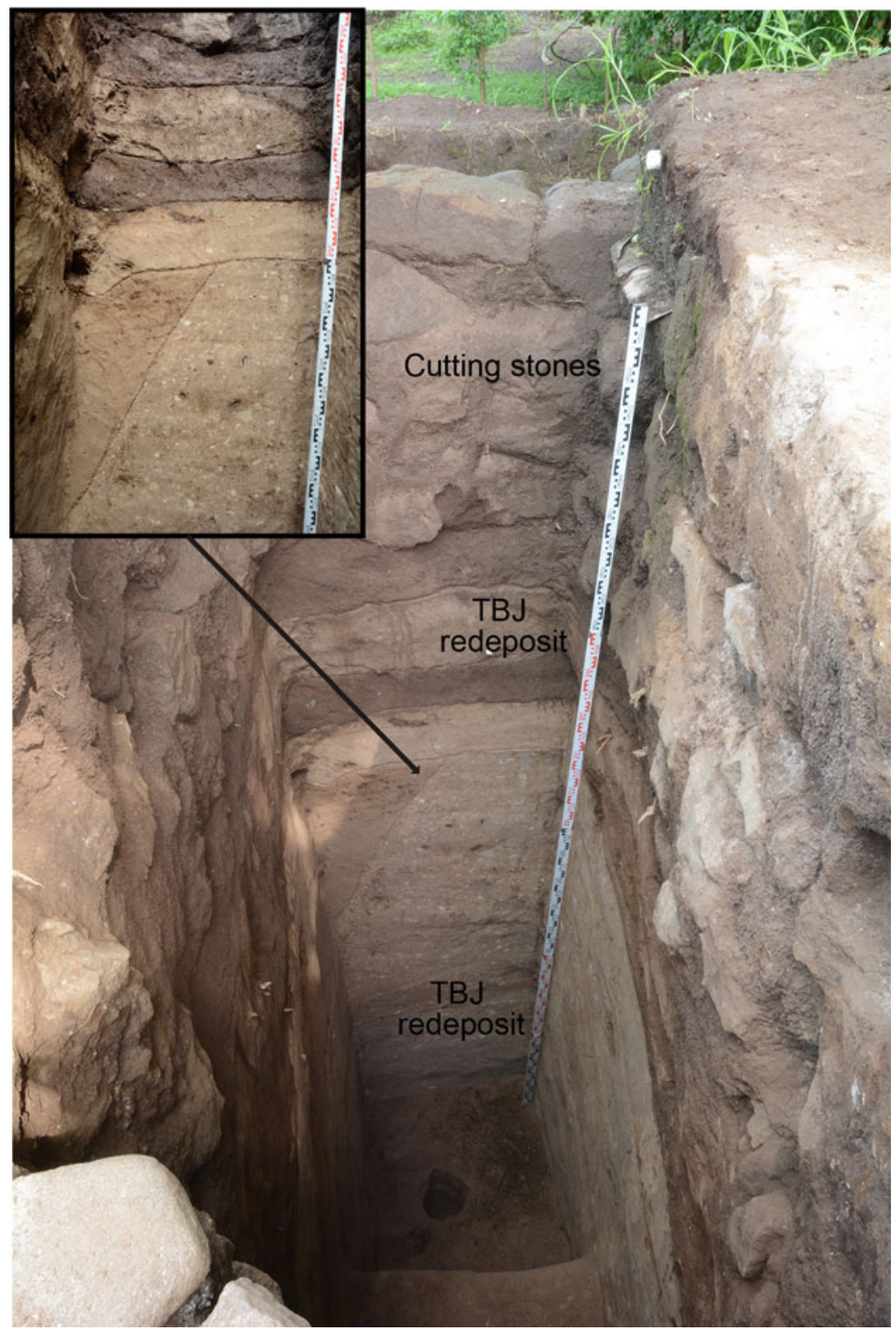

Figure 4. Large amount of the TBJ tephra redeposited found at Tr.5. (Photographs by Akira Ichikawa.)

large cut-stone blocks); TBJ tephra was no longer used as a construction material (Supplemental Figure 1). The Campana Structure platform was expanded to approximately $85 \times$ $65 \mathrm{~m}$ and $7 \mathrm{~m}$ in height (Figure 3b). Excavations also encountered ritual offerings associated with the adobe construction phase, most likely deposited during the initial construction stage, such as an offering in a slab-lined pit on the platform's centerline (Figure 3b). Offerings included two vessels, one containing a jade-carved doubleheaded serpent; another incomplete jade artifact; two Spondylus shells; and a stone ball with red pigment (Figure 5).

The size of the adobe at San Andrés varied from 46 to $64 \mathrm{~cm}$ in length, 25 to $35 \mathrm{~cm}$ in width, and 15 to $18 \mathrm{~cm}$ in thickness (Ichikawa and Rodas 2020). Furthermore, different colors 


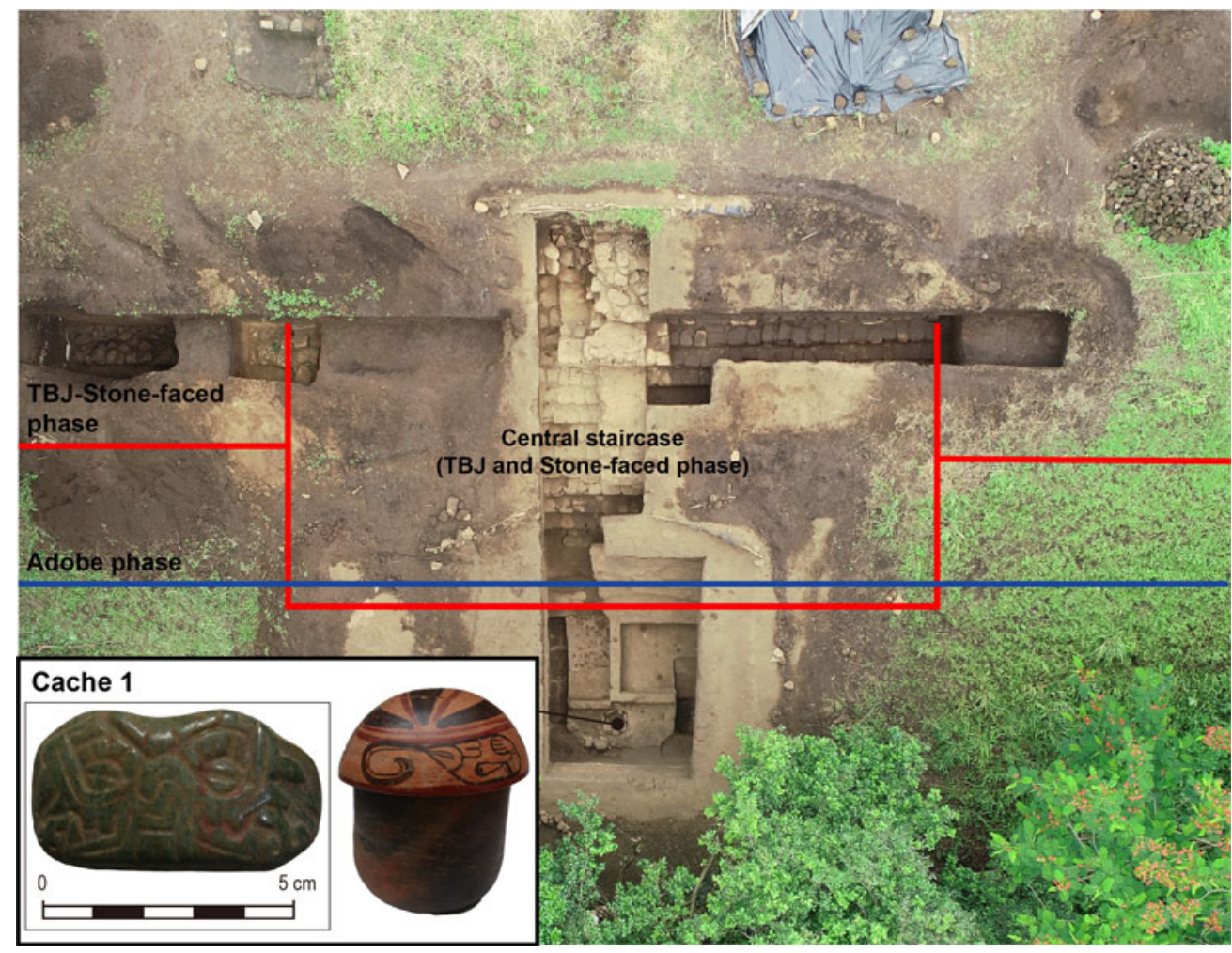

Figure 5. Central staircase of TBJ stone-faced phase, adobe phase, and cache 1 at the Campana Structure. (Photographs by Akira Ichikawa.)

and textures could indicate that the recipe for making the adobes varied. The mud plaster (average thickness, $5 \mathrm{~cm}$ ) was composed of roughly $60 \%$ black or brown lapilli, measuring $5-15 \mathrm{~mm}$, and silty clay. Ceramics recovered from adobe construction fill are mainly of the Guazapa group but also include several polychromes such as Copador, Gualpopa, and Campana ceramics, time indicators of the Late Classic period in western-central El Salvador (Sharer 1978).

The excavation data provide information about the collapse of the Late Classic monumental core of San Andrés. Only the Campana Structure platform's first terrace was well preserved, and layers between the floor and the El Boquerón (EB) tephra, which is $0.5-1.0 \mathrm{~m}$ thick, include collapse debris. Other excavated areas in San Andrés also indicate that layers between the EB tephra and the final phase of construction include collapse debris. such as adobes and mud plasters (Camacho and Díaz 2015). This suggests that the
Late Classic monumental core of San Andrés was highly eroded long before the eruption (Figure 6).

Architectural and stratigraphic data show that the monumental core of San Andrés was reoccupied during the Early Postclassic, maybe a few centuries after the Late Classic abandonment, and after the EB eruption. The Mound B platform, located west of the Campana Structure, rests on the EB tephra (Card 1997:53). Further, approximately $5 \mathrm{~cm}$ of black soil was recorded between the platform's basal part and the EB tephra (Card 1997:53). This black soil located between the EB tephra and subsequent construction was also confirmed in the Acropolis (Amaroli 2015:255). This indicates a time lapse between these two events. Mound B, measuring approximately $25 \times 15 \mathrm{~m}$ and at least $1.4 \mathrm{~m}$ in height, is constructed with volcanic tuff locally known as talpetate. The characteristics, sizes, and forms of these volcanic tuff blocks differ from those used for the TBJ and stone-faced 


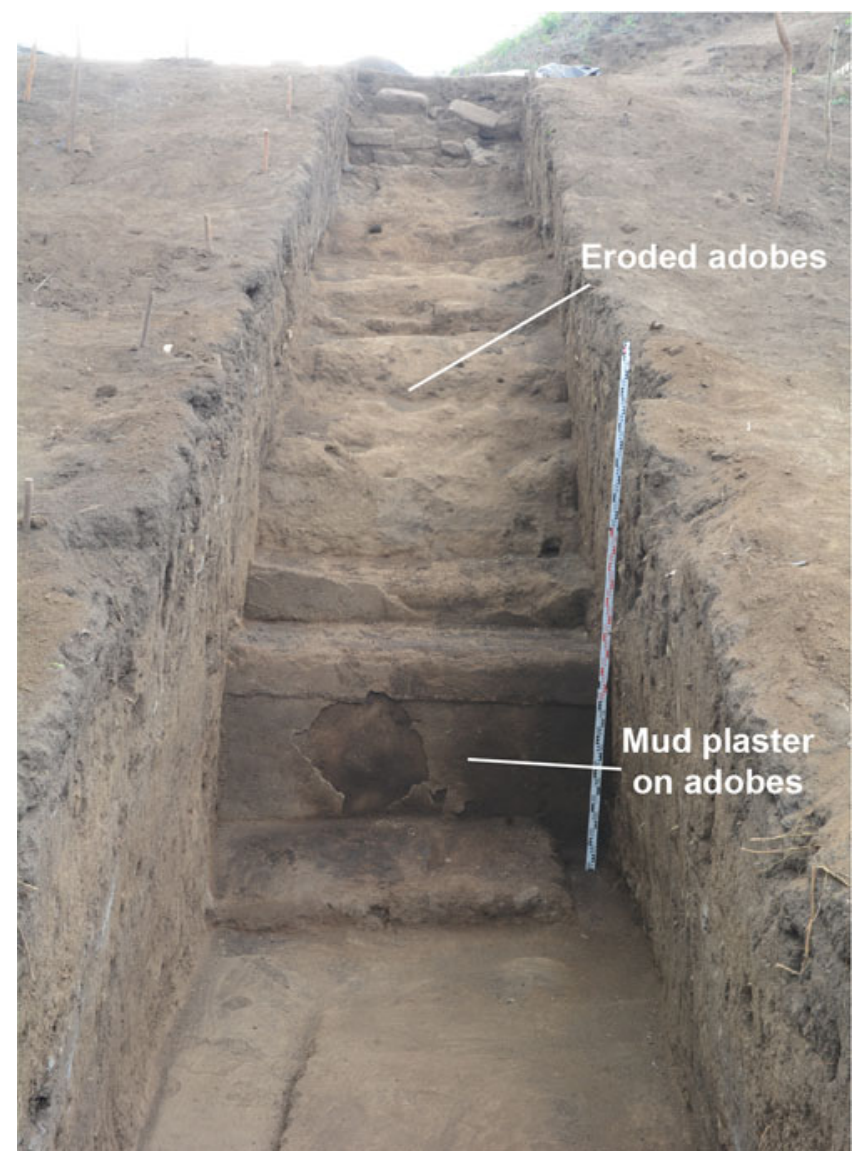

Figure 6. First terrace of adobe construction phase coating by mud plaster. (Photograph by Akira Ichikawa.)

phases of the Campana Structure. The Mound B talpetate blocks are porous; their size and form are fairly standardized and rectangular, measuring $40 \times 25 \times 20 \mathrm{~cm}$. The blocks were observed in the pyramidal structure on the Campana Structure platform and the Acropolis. The ones used for the Campana Structure are interpreted as evidence of reconstruction during the prehispanic period, because they were placed on top of the original adobe and mud-plastered finish that had eroded substantially (Card 1997:42). Mixteca-Puebla-style potsherds were recovered only above the EB deposit, suggesting that Pipil migrants or local groups influenced by Central Mexican traditions may have occupied the area after the EB eruption.

These excavation data significantly enhance our understanding of the rise, development, and fall of San Andrés. The results of 26 radiocarbon dates from this and other Zapotitán Valley sites presented in the next section further enhance our understanding of these events.

\section{Radiocarbon Dates}

The Bayesian analysis results are shown in Figures 7 and 8 and the OxCal code in Supplemental Text 1. The final Bayesian model produced in OxCal has both a good model agreement index value $\left(A_{\text {moldel }}=88.7 \%\right)$ and individual agreement value $\left(A_{\text {overall }}=86.5 \%\right)$.

The Bayesian model indicates that the TBJ eruption may be dated to around AD 539-540 and the TBJ-earth construction phase to around AD 545-570. Although these carbon samples may be extracted from old contexts, the model suggests that the TBJ-earth construction phase building project began within decades of the TBJ eruption. The TBJ and stone-faced 


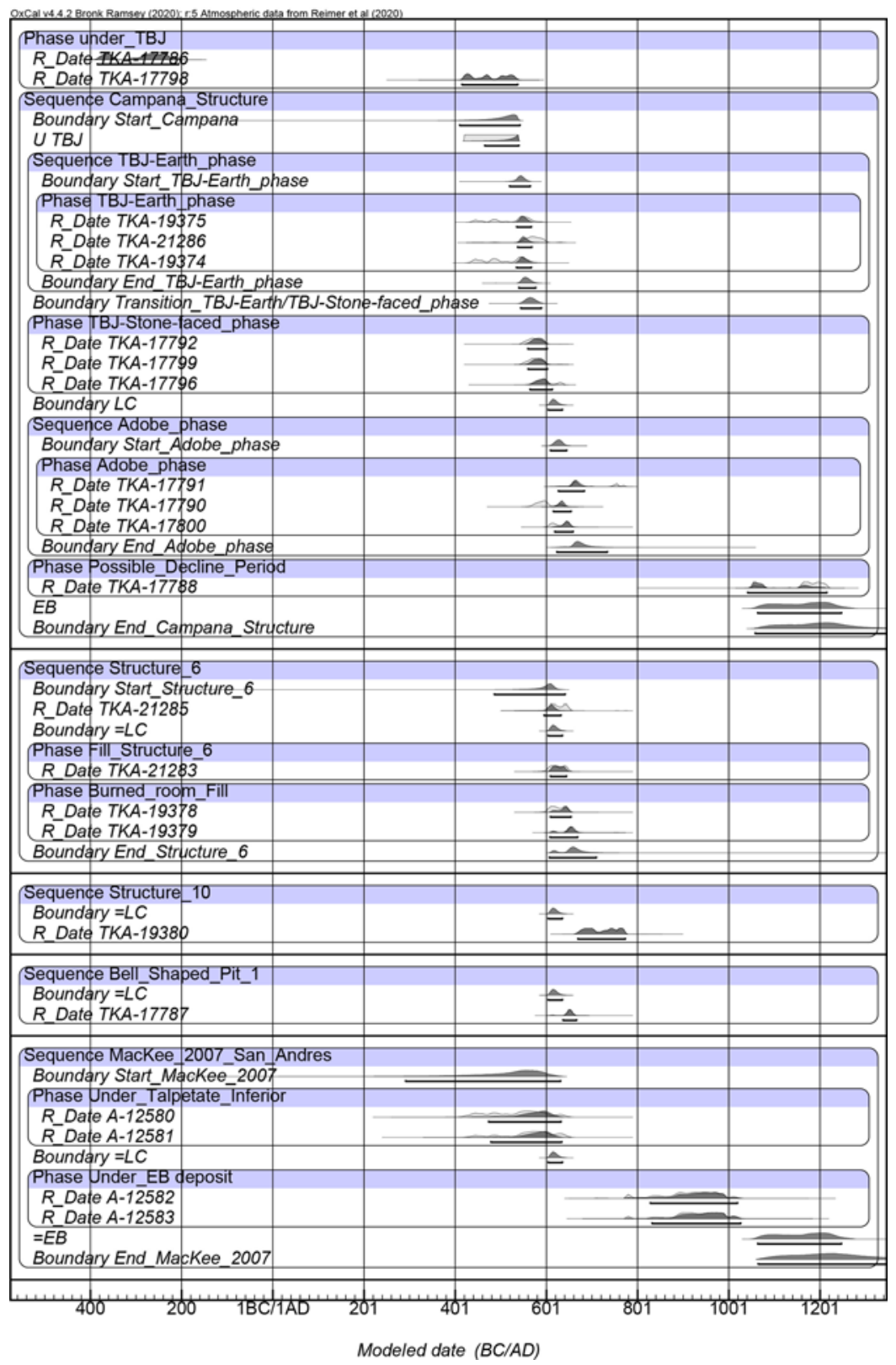

Figure 7. Bayesian model for San Andrés chronology.

construction phase are dated to approximately AD 570-620. These carbon samples were dated to after the ${ }^{14} \mathrm{C}$ calibration curve plateau (1600-1550 yr BP), indicating they were clearly from after the TBJ eruption. Bayesian modeling indicated that the LC eruption was plausibly around AD 620. These data imply that a monumental building project and its renovation occurred within a few decades-within a maximum of 80 years - after the TBJ eruption. The adobe phase of construction is dated to $\mathrm{AD}$ 625-800. El Cambio and Nuevo Lourdes Poniente correspond to this period. Carbon samples from layers between the final floor level and the EB tephra are dated to approximately AD 900-1050. Evidence of considerable erosion of 


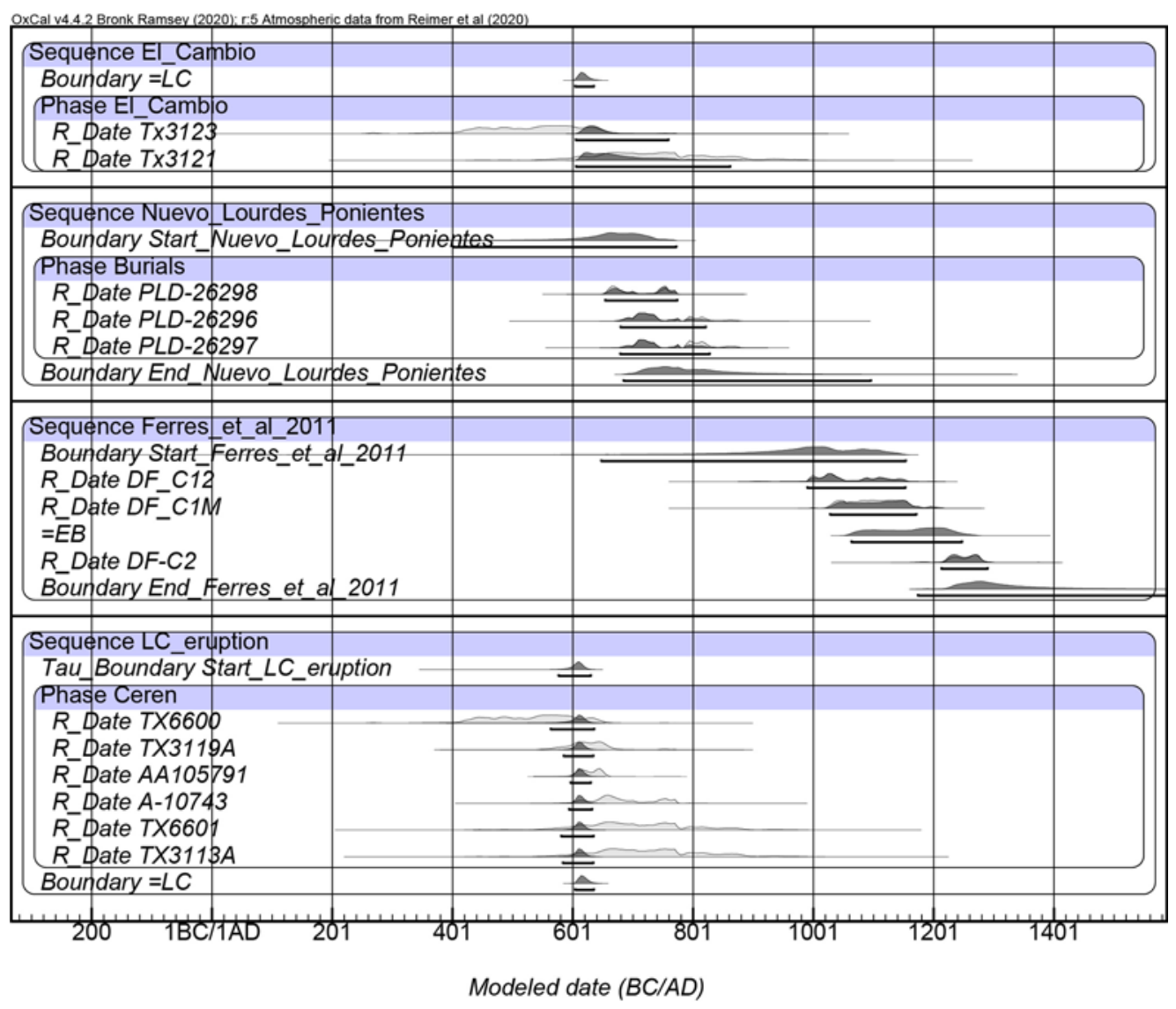

Figure 8. Bayesian model for sites in the Zapotitán Valley.

the Campana Structure and no further building renovation in this period indicates decline or abandonment of the site. Unfortunately, estimates for the date of the EB eruption range widely, from AD 1050 to 1250, and will need to be revised in the future to obtain a more accurate estimate.

\section{Discussion}

\section{TBJ Eruption}

New excavation and radiometric data suggest that San Andrés was a small village dedicated to ceramic production and agriculture during the Late/Terminal Preclassic period. In the first portion of the Early Classic period before the TBJ eruption, social activities at San Andrés probably declined, as suggested by the low quantities of Early Classic ceramics. The relatively larger quantities of such ceramics found in other sites, such as Nuevo Lourdes Poniente and El Cambio, suggest they may have been of greater importance and also that Early Classic settlement may have been more scattered than previously thought. It is important to note that Guazapa, and Chilanga ceramics, usually found in the context above the TBJ tephra (Sharer 1978), began to be produced before the TBJ eruption in the Zapotitán Valley.

The Bayesian model using available data suggests an approximate date of AD 539-540 for the TBJ eruption. However, more data are needed to verify this model, so the alternative estimate of AD 431 (Smith et al. 2020) should not be discarded. Although the TBJ eruption's magnitude could have been catastrophic, it is unlikely that existing societies in the Zapotitán Valley were completely wiped out, as previously proposed (Dull et al. 2019; Pedrazzi et al. 2019; Sheets 2004, 2012). Excavations and radiometric dates 
suggest the TBJ-earth architecture was built in AD 545-570 and, subsequently, the TBJ and stone-faced architecture in AD 570-620. This is significant because it demonstrates that monumental architecture was constructed earlier than the mid-seventh century, as argued by Dull and coworkers (2019). In addition, as Dull and colleagues estimated (2019:14), if the Zapotitán Valley population had drastically decreased, limited numbers of people would have been available to construct the structure. This would mean that people reoccupied San Andrés and were cooperating to build monumental architecture within a remarkably quick 30 years or, at the latest, 80 years after the eruption if the $\mathrm{AD}$ 539-540 date were accepted. Even if the date of AD 431 proposed by Smith and colleagues (2020) is correct, the site was still reoccupied within around 120 years of the eruption or even earlier, as indicated by the significant continuity of ceramic groups such as the dominant utilitarian Guazapa ceramic group.

Furthermore, these results give us reason to question previous theories about the identities of the valley's Late Classic populations. It has been proposed, based on material and architectural similarity, that the first reoccupants of the Zapotitán Valley after the TBJ eruption were Ch'orti' immigrants from the Copan Valley (Sheets 2009). However, the Guazapa ceramic group, the dominant utilitarian vessel in Cerén and other Zapotitán Valley sites, existed before the TBJ eruption and continued to be used after the eruption, and other significant ceramic continuities exist between contexts above and below TBJ deposits. Thus, the impact of the eruption in the Zapotitan Valley may not have been as severe as once thought; some local populations may have survived there. Alternatively, descendants of pre-TBJ populations may have first evacuated and then later reoccupied their homeland. Additional research is required to explore these scenarios more rigorously.

This work also highlights the use and reuse of volcanic material as a construction material. The use of considerable amounts of TBJ tephra for the Campana Structure's monumental architecture may have had important practical and symbolic implications. The presence of volcanic fumes, fires, a landscape completely covered with white volcanic ash, and (in all likelihood) frequent earth tremors would have had a significant psychological impact on survivors or subsequent colonizers in the region (Dull et al. 2019:14). Volcanoes/mountains are deeply embedded in ancient Mesoamerican life (Freidel et al. 1993; Joyce 2020; Plunket and Urñuela 2008), and the use and reworking of volcanic material by builders may have preserved memories of catastrophic volcanic disasters in the collective memory. The variations in the mixed TBJ redeposit indicate that different workgroups participated in this building project, which would have reinforced a corporate identity among them. However, the practical qualities of TBJ tephra as a construction material must also be mentioned. As Sheets and colleagues (2015:354) point out, the TBJ tephra has excellent compaction properties and is still used for construction today. Likewise, variations in the TBJ redeposit were also observed in Cerén, suggesting different workgroups or building episodes (Sheets et al. 2015:355).

\section{Cerén and San Andrés}

The new stratigraphic data from San Andrés raise questions about the relationship between Cerén and San Andrés. It has been assumed that San Andrés's elite rulers controlled the political and economic aspects of the valley when the Cerén village existed (Sheets 2009). However, excavation data suggest that the Acropolis, the North Plaza (possibly a marketplace), eccentric flint, and other rich ritual offerings in San Andrés correspond to the post-LC eruption context. Previous research at the Acropolis indicated that it comprises several architectural units made entirely of adobe and mud plaster (Amaroli 2015; Boggs 1943; Dimick 1941). The only structure as yet identified as contemporary with Ceren is the Campana Structure's TBJ and stonefaced phase. Furthermore, the archaeological material recovered from the context of the LC and TBJ eruptions is very limited. This suggests that when Cerén existed, San Andrés may have been a focal point of the materialized memory of previous catastrophic eruptions and had a regional community identity as a symbol of the post-TBJ eruption recovery process. It is, however, far from clear that San Andrés was a political or economic center by this time. Cerén 
commoners may have had greater autonomy than once proposed to develop connections with other distant primary centers such as Chalchuapa and Copan.

\section{San Andrés's Apogee: Loma Caldera Eruption}

After the LC eruption, around AD 620, San Andrés became the Zapotitán Valley's primary religious, political, and economic center. The eruption, earthquakes, and villages buried in volcanic tephra must have had a strong psychological impact on the people in the valley. However, the environmental impact was less than that of the TBJ eruption; a large cultural disjuncture did not occur (Sheets 2008:79), and the population increased by 40,000-100,000 (Black 1983). The use of TBJ tephra and stone-facing techniques was discontinued. Instead, monumental public constructions were constructed with adobe and mud plaster. Adobe production existed before the LC eruption in Cerén, but at that time these adobes were probably property intersection markers (Sheets et al. 2012:265, 271) and not used for construction. Mudplastering techniques also existed prior to the LC eruption in limited contexts such as hardened floors.

Adobe and mud-plaster techniques were exclusively used for monumental public buildings in the valley after the LC eruption. Large amounts of adobe blocks indicate that San Andrés was a locus of significant labor investment. In addition, different adobe sizes and materials suggest that different adobe artisans in the valley gathered at San Andrés to construct monumental public buildings (Ichikawa and Rodas 2020). The quality of the mud-plastering techniques was enhanced using black lapilli, whose inclusion seems to have been inspired by the LC tephra, which contains large amounts of lapilli units. This use of a new material produced as a result of the volcanic eruption may have been for both religious and practical reasons.

During the construction of the Campana Structure and the Acropolis, multiple audiences could have shared ritual practices, as evidenced by human sacrifices, several offering vessels, ceramic incense burners, and carved sculptures of serpents, a parrot, a frog, and a human figure
(Boggs 1943). These practices could have contributed to forming local identities and, simultaneously, formalizing social inequality and the centralization of regional political authority. With restricted access and limited visibility from outside the Acropolis, the Acropolis plaza was probably used for elite rituals, suggesting that political power became more exclusive than previously (Boggs 1943).

However, the political system centered at San Andrés had likely disintegrated by AD 800, long before the subsequent EB eruption. No radiocarbon samples from adobe structures from after AD 800 have been run. Furthermore, the layers between the final level of the mud-plastered floor and the EB tephra recorded in the Campana Structure and the Acropolis have a maximum thickness of $1 \mathrm{~m}$; they consistently contain a considerable amount of collapsed debris, suggesting that the monumental core of San Andrés was highly eroded by the time of the EB eruption. In addition, there is evidence that the terminal phase of the Acropolis may have been burned (Amaroli 2015:265). Thus, the EB eruption was clearly not responsible for the abandonment of the ceremonial core at San Andrés. Other suggested causes are the arrival of immigrants from Central Mexico (though clear evidence of that only appears after the EB eruption) or a decline due to internal problems (though this last is purely speculative)

\section{El Boquerón Eruption}

Bayesian modeling estimated the EB eruption date as AD 1050-1250. The layers between the EB tephra and the talpetate block construction in Mound B and the Acropolis suggest that reoccupation of San Andrés's monumental core may have occurred several decades after the EB eruption. This is because the compactness and hardness of the tephra would have damaged agriculture (Sheets 2004:116). The timing of the Late Classic decline, the recovery of agricultural fields, and the lack of Late Postclassic material suggest the eruption presumably occurred around AD 1050 or earlier, as indicated by Ferrés and colleagues (2011). Although a recent study based on the isopach map suggests that $21,000-54,000$ people were affected by the eruption, demographic recoveries from the EB 
eruption occurred a few decades later with no cultural disjuncture (Sheets 2004:117).

However, after the EB eruption, migrants or a new group influenced by Central Mexican traditions may have occupied San Andrés, renovating monumental architecture built a few centuries before, including the Campana Structure and Acropolis. New occupants used talpetate blocks, which were not available before the eruption (Begley et al. 1997:103), to repair and reuse these earlier structures, treating earlier sacred spaces with reverence. Although it is not certain whether the new builders, who probably were migrants or members of new groups influenced by Central Mexican traditions, witnessed the EB eruption, they might have conceived the innovative use of talpetate blocks, products of the EB eruption, and reconstructed old sacred spaces.

\section{Conclusions}

New excavation and radiocarbon data significantly clarify the development, rise, and decline of San Andrés and the impacts of volcanic eruptions on its settlement history and culture. These data suggest that populations in San Andrés were affected and possibly displaced multiple times by volcanic eruptions, yet resilient populations quickly reoccupied and rebuilt the site in the decades after these eruptions. These periods of renewal led to novel architectural - and, likely by extension-social, and ritual practices at the site. As several scholars argue (Hoffman 1999; Oliver-Smith 1996; Torrence 2019), the data suggest that abrupt environmental changes caused by volcanic eruptions, especially the TBJ and LC eruptions, were opportunities for local leaders to create new communal affiliations and regional-scale corporate identities, rather than resulting in periods of total societal collapse. These periods of centralization are evidenced by the monumental public building projects, requiring large amounts of labor, which seem to have been rapidly organized after each eruption. The EB eruption was not responsible for the Late Classic collapse of San Andrés, and its timing and impacts need to be investigated further. The new occupants seemed to have been inspired by the volcanic products that covered the valley and, using this material, reconstructed old sacred spaces. The principal factor in the choice of construction materials is often its environmental availability (Blake 1988:36). During different eruption periods in the Zapotitán Valley, as in the Mediterranean (Chester et al. 2005), people used new innovative construction materials, volcanic products, and methods of labor organization to construct monumental architecture as a social response to eruptions. This use of volcanic products as construction material embraced a religious/symbolic meaning, as well as a practical use.

Obtaining more radiocarbon dates from secure contexts and combining them with other archaeological evidence are required to advance this research. Using Bayesian modeling, this study prefers the AD 539-540 for the TBJ eruption, but the possibility of the AD 431 eruption date should not be discarded (Smith et al. 2020). If the earlier date is correct, the social response in the Zapotitan Valley was initiated earlier than the assumption proposed here, and the recovery process was slower or more gradual rather than drastic. To advance the discussion, data from Chalchuapa, Cara Sucia, and Quelepa-regional primary centers affected by the TBJ eruption - should be included. Recent discussions have focused only on eruption dates. However, discussions based on archaeological evidence alone are insufficient due to the lack of archaeological investigations focusing on the TBJ eruption. Further AMS radiocarbon dating is also needed to date the LC eruption. This study argues that the EB eruption did not cause the Late Classic abandonment or social change during the Early Postclassic period. Nevertheless, further data will be needed to develop a similar discussion for other eruptions.

The data presented here and future research in San Andrés will provide useful information for reimagining southeastern Mesoamerica's social dynamics and human responses to volcanic eruptions. Further investigation at San Andrés will enhance our understanding of the political and economic dynamics at Cerén and give a broader understanding of the degree and extent of the power of the Copan dynasty in El Salvador and southeastern Mesoamerica. 
Acknowledgments. I am grateful to the Dirección de Arqueología de la Dirección Nacional de Patrimonio Cultural, Ministerio de Cultura, El Salvador; Nagoya University; and the University of Colorado Boulder for their invaluable support. This research was supported by grants from the JSPS KAKENHI (\#26101003, 19H05734, and 19K13400), Mitsubishi Foundation, and Inamori Foundation in Japan. I also gratefully acknowledge helpful feedback on early drafts of this article and encouragement from Arthur Joyce, Payson Sheets, Erlend Johnson, and Shigeru Kitamura. Finally, I thank the three anonymous reviewers for their insightful comments that improved this article.

Data Availability Statement. The excavated materials are available in the Dirección de Arqueología de la Dirección Nacional de Patrimonio Cultural, Ministerio de Cultura, El Salvador. All digital and analysis data were generated by the author and are available for research purposes by contacting him.

Supplemental Material. To view supplemental material for this article, please visit https://doi.org/10.1017/laq.2021.28.

Supplemental Figure 1. Matrix indicating the stratigraphic relations and radiocarbon samples.

Supplemental Table 1. Radiocarbon dates from San Andrés.

Supplemental Table 2. Radiocarbon dates from sites in the Zapotitán Valley.

Supplemental Text 1. OxCal code (OxCal v.4.4.2).

\section{References Cited}

Amaroli, Paul

2015 Arqueología de El Salvador. FUNDAR, El Salvador.

Balmuth, Miriam S., David K. Chester, and Patricia A. Johnston (editors)

2005 Cultural Responses to the Volcanic Landscapes: The Mediterranean and Beyond. Archaeological Institute of America, Boston.

Begley, Christopher, Roberto Gallardo, Jeb Card, Alex Wilson, Linda Brown, and Norman Hermann

1997 Proyecto Arqueológico San Andrés: Informe 1997. Report prepared for the Patronato Patrimonio Cultural, El Salvador.

Black, Kevin D.

1983 The Zapotitán Valley Archeological Survey. In Archeology and Volcanism in Central America: The Zapotitán Valley of El Salvador, edited by Payson Sheets, pp. 62-98. University of Texas Press, Austin.

Blake, Susan

1988 House Materials, Environment, and Ethnicity in Southeastern Chiapas, Mexico. In Ethnoarchaeology among the Highland Maya of Chiapas, Mexico, edited by Thomas A. Lee Jr. and Brian Hayden, pp. 21-37. New World Archaeological Foundation, Brigham Young University, Provo, Utah.

Boggs, Stanley H.

1943 Notas sobre las excavaciones en la Hacienda "San Andrés" Departamento de la Libertad. Tzunpame 3:104-126.
Bronk Ramsey, Christopher

2009 Bayesian Analysis of Radiocarbon Dates. Radiocarbon 51:337-360.

2020 OxCal v.4.4.2. Released 2020 August 19. Oxford Radiocarbon Accelerator Unit (ORAU). Electronic document, http://c14.arch.ox.ac.uk, accessed January $10,2021$.

Camacho, Oscar, and Hugo Díaz

2015 Análisis de los materiales arqueológicos de las Temporadas 2011-2012, del Proyecto Arqueológico San Andrés, Valle de Zapotitán, El Salvador. In XXVIII Simposio de Investigaciones Arqueológicas en Guatemala, edited by Bárbara Arroyo, Luis Méndez Salinas, and Lorena Paiz, pp. 433-440. Museo Nacional de Arqueología y Etnología, Guatemala City.

Card, Jeb J.

1997 Excavations on Mound B. In Proyecto Arqueológico San Andrés: Informe 1997, edited by Christopher Begley, Roberto Gallardo, Jeb Card, Aixa Wilson, Linda Brown, and Nicholas Herrmann, pp. 50-67. Report prepared for the Patronato Patrimonio Cultural, El Salvador.

Chandler, Susan M.

1983 Excavations at the Cambio Site. In Archaeology and Volcanism in Central America: The Zapotitán Valley of El Salvador, edited by Payson Sheets, pp. 98-118. University of Texas Press, Austin.

Chester, David K., Angus M. Duncan, and John E. Guest

2005 Responses to Eruptions of Etna from the Classical Period to 1900. In Cultural Responses to Volcanic Landscapes: The Mediterranean and Beyond, edited by Miriam S. Balmuth, David K. Chester, and Patricia A. Johnston, pp. 93-108. Archaeological Institute of America, Boston.

Cooper, Jago, and Payson D. Sheets (editors)

2012 Surviving Sudden Environmental Change: Answers from Archaeology. University Press of Colorado, Boulder.

Dimick, John

1941 Notes on Excavations at Campana-San Andrés, El Salvador. In Carnegie Institution of Washington Year Book No. 40: July 1, 1940-June 30, 1941, pp. 298300. Carnegie Institution, Washington, DC.

Dull, Robert A., John R. Southon, Steffen Kutterolf, Kevin J. Anchukaitis, Armin Freundt, David B. Wahl, Payson Sheets, Paul Amaroli, Walter Hernandez, Michael C. Wiemann, and Clive Oppenheimer

2019 Radiocarbon and Geologic Evidence Reveal Ilopango Volcano as Source of the Colossal "Mystery" Eruption of 539/540 CE. Quaternary Science Reviews 2221-2217.

Dull, Robert A., John R. Southon, and Payson Sheets

2001 Volcanism, Ecology and Culture: A Reassessment of the Volcán Ilopango TBJ Eruption in the Southern Maya Realm. Latin American Antiquity 12:25-44.

Fash, Williams, and Leonardo López Luján (editors)

2009 The Art of Urbanism: How Mesoamerican Kingdoms Represented Themselves in Architecture and Imagery. Dumbarton Oaks, Washington, DC.

Ferrés, Dolores, Hugo Delgado Granados, Walter Hernández, Carlos Pullinger, Hugo Chávez, Rafael Castillo Taracena, and Carlos Cañas Dinarte

2011 Three Thousand Years of Flank and Central Vent Eruptions of the San Salvador Volcanic Complex (El Salvador) and their Effects on the El Cambio Archeological Site: A Review Based on Tephrostratigraphy. Bulletin of Volcanology 73:833-850. 
Freidel, David A., Linda Schele, and Joy Parker 1993 Maya Cosmos: Three Thousand Years on the Shaman's Path. William Morrow, New York.

Grattan, John

2006 Aspects of Armageddon: An Exploration of the Role of Volcanic Eruptions in Human History and Civilization. Quaternary International 151:10-18.

Grattan, John, and Robin Torrence

2007 Beyond Gloom and Doom: The Long-Term Consequences of Volcanic Disasters. In Living under the Shadow: The Cultural Impacts of Volcanic Eruptions, edited by John Grattan and Robin Torrence, pp. 1-18. Left Coast Press, Walnut Creek, California.

Hoffman, Susanna

1999 After Atlas Shrugs: Cultural Change or Persistence after a Disaster. In The Angry Earth: Disaster in Anthropological Perspective, edited by Anthony OliverSmith and Susanna Hoffman, pp. 302-325. Routledge, London.

Ichikawa, Akira, Roberto Gallardo, Hugo Díaz, and Julio Alvarado

2014 Nuevo datos de radiocarbono relacionados con la erupción del Volcán Ilopango. Anales del Museo Nacional de Antropología "Dr. David J. Guzmán” El Salvador 53:160-175.

Ichikawa, Akira, and Angel Rodas

2020 Manufacturing Adobe Bricks in Mesoamerica: Archaeological and Experimental Analysis from San Andrés, El Salvador. Mexicon 42:153-160.

Inomata, Takeshi, Raul Ortiz, Bárbara Arroyo, and Eugenia J. Robinson

2014 Chronological Revision of Preclassic Kaminaljuyú, Guatemala: Implications for Social Processes in the Southern Maya Area. Latin American Antiquity 25:377-408.

Joyce, Arthur

2020 Assembling the City: Monte Alban as a Mountain of Creation and Sustenance. In New Materialism, Ancient Urbanisms, edited by Susan M. Alt and Timothy R. Pauketat, pp. 65-93. Routledge, London.

Kintigh, Keith W., Jeffrey H. Altschul, Mary C. Beaudry, Robert D. Drennan, Ann P. Kinzig, Timothy A. Kohler, W. Fredrick Limp, Herbert D. G. Maschner, William K. Michener, Timothy R. Pauketat, Peter Peregrine, Jeremy A. Sabloff, Tony J. Wilkinson, Henry T. Wright, and Melinda A. Zeder

2014 Grand Challenges for Archaeology. American Antiquity 79:5-24.

McKee, Brian R.

2002 Introduction: Appendix 1A: Radiocarbon Dating and Chronology. In Before the Volcano Erupted: The Ancient Cerén Village in Central America, edited by Payson Sheets, pp. 7-8. University of Texas Press, Austin.

2007 Volcanism, Household Archeology, and Formation Processes in the Zapotitán Valley, El Salvador. PhD dissertation, Department of Anthropology, University of Arizona, Tucson.

Mejia, Jorge

1984 Las ruinas de San Andrés: Excavaciones en la Estructura No. 7. Flama 14(48):33-47.

Miller, C. Dan

2002 Volcanology, Stratigraphy, and Effects on Structures. In Before the Volcano Erupted: The Ancient Cerén Village in Central America, edited by Payson Sheets, pp. 11-23. University of Texas Press, Austin.
Oliver-Smith, Anthony

1996 Anthropological Research on Hazards and Disasters. Annual Review of Anthropology 25:303-328

Oliver-Smith, Anthony, and Susanna M. Hoffman (editors) 1999 The Angry Earth: Disaster in Anthropological Perspective. Routledge, London.

Pedrazzi, Dario, Ivan Sunye-Puchol, Gerardo Aguirre-Díaz, Antonio Costa, Victoria C. Smith, Matthieu Poret, Pablo Dávila-Harris, Daniel P. Miggins, Walter Hernández, and Eduardo Gutiérrez.

2019 The Ilopango Tierra Blanca Joven (TBJ) Eruption, El Salvador: Volcano Stratigraphy and Physical Characterization of the Major Holocene Event of Central America. Journal of Volcanology and Geothermal Research 377:81-102.

Plunket, Patricia, and Gabriela Uruñuela

2005 Recent Research in Puebla Prehistory. Journal of Archaeological Research 13:89-127.

2008 Mountain of Sustenance, Mountain of Destruction: The Prehispanic Experience with Popocatépetl Volcano. Journal of Volcanology and Geothermal Research 170:111-120.

Reimer, Paula J., William E. N. Austin, Edouard Bard, Alex Bayliss, Paul G. Blackwell, Christopher Bronk Ramsey, Martin Butzin, Hai Cheng, R. Lawrence Edwards, Michael Friedrich, Pieter M. Grootes, Thomas P. Guilderson, Irka Hajdas, Timothy J. Heaton, Alan G. Hogg, Konrad A. Hughen, Bernd Kromer, Sturt W. Manning, Raimund Muscheler, Jonathan G. Palmer, Charlotte Pearson, Johannes van der Plicht, Ron W. Reimer, David A. Richards, E. Marian Scott, John R. Southon, Christian S. M. Turney, Lukas Wacker, Florian Adolphi, Ulf Büntgen, Manuela Capano, Simon M. Fahrni, Alexandra Fogtmann-Schulz, Ronny Friedrich, Peter Köhler, Sabrina Kudsk, Fusa Miyake, Jesper Olsen, Frederick Reinig, Minoru Sakamoto, Adam Sookdeo, and Sahra Talamo

2020 IntCal20 Northern Hemisphere Radiocarbon Age Calibration Curve $(0-55$ cal kBP). Radiocarbon 62:725-757.

Scarth, Alwyn

1999 Vulcan's Fury: Man against the Volcano. Yale University Press, New Haven, Connecticut.

Sharer, Robert J.

1978 The Prehistory of Chalchuapa, El Salvador, Vols. IIII. University of Pennsylvania Press, Philadelphia.

Sheets, Payson D.

2000 Provisioning the Cerén Household: The Vertical Economy, Village Economy, and Household Economy in the Southeastern Maya Periphery. Ancient Mesoamerica 11:217-230.

2004 Apocalypse Then: Social Science Approaches Volcanism, People, and Cultures in the Zapotitán Valley, El Salvador. In Natural Hazards in El Salvador, edited by William I. Rose, Julian J. Bommer, Dina L. López, Michael J. Carr, and Jon J. Major, pp. 147-158. GSA Special Papers Vol. 375. Geological Society of America, Boulder, Colorado.

2008 People and Volcanos in the Zapotitan Valley, El Salvador. Living under the Shadow: Cultural Impacts of Volcanic Eruptions, edited by John Grattan and Robin Torrence, pp. 67-89. Routledge; London.

2009 Who Were those Classic Period Immigrants into the Zapotitán Valley, El Salvador? In The Ch'orti' Maya Area: Past and Present, edited by Brent E. Metz, Cameron L. McNeil, and Kerry M. Hull, pp. 61-77. University Press of Florida, Gainesville. 
2012 Responses to Explosive Volcanic Eruptions by Small-to-Complex Societies in Ancient Mexico and Central America. In Surviving Sudden Environmental Change: Answers from Archaeology, edited by Jago Cooper and Payson D. Sheets, pp. 43-63. University Press of Colorado, Boulder.

2016 Thoughts and Observations on Volcanic Activity and Human Ecology. Quaternary International 394: $152-154$.

Sheets, Payson D. (editor)

1983 Archaeology and Volcanism in Central America: The Zapotitán Valley of El Salvador. University of Texas Press, Austin.

2002 Before the Volcano Erupted: The Ancient Cerén Village in Central America. University of Texas Press, Austin.

Sheets, Payson D., Christine Dixon, David Lentz, Rachel Egan, Alexandria Halmbacher, Venicia Slotten, Rocio Herrera, and Celine Lamb

2015 The Sociopolitical Economy of an Ancient Maya Village: Cerén and Its Sacbe. Latin American Antiquity 26:341-361.

Sheets, Payson D., David Lentz, Dolores Piperno, John Jones, Christine Dixon, George Maloof, and Angela Hood

2012 Ancient Manioc Agriculture South of the Ceren Village, El Salvador. Latin American Antiquity 23:259-281.

Shibata, Shione, and Rocío Herrera

2019 Continuidad o abandono? El centro ceremonial de Tazumal, El Salvador C.A. después de la erupción del Volcán Ilopango entre el siglo V-VI d.C. Kóot 10:92-135.

Slotten, Venicia

2015 Paleoethnobotanical Remains and Land Use Associated with the Sacbe at the Ancient Maya Village of
Joya de Cerén. Master's thesis, Department of Anthropology, University of Cincinnati, Ohio.

Smith, Victoria C., Antonio Costa, Gerardo Aguirre-Díaz, Dario Pedrazzi, Andrea Scifo, Gill Plunkett, Mattieu Poret, Pierre-Yves Tournigand, Dan Miles, Michael W. Dee, Joseph R. McConnell, Ivan Sunyé-Puchol, Pablo Dávila Harris, Michael Sigl, Jonathan R. Pilcher, Nathan Chellman, and Eduardo Gutiérrez.

2020 The Magnitude and Impact of the 431 CE Tierra Blanca Joven Eruption of Ilopango, El Salvador. PNAS 117:26061-26068.

Sofield, Darrel J.

2004 Eruptive History and Hazards of Volcan San Salvador, El Salvador. In Natural Hazards in El Salvador, edited by William I. Rose, Julian J. Bommer, Dina L. López, Michael J. Carr, and Jon J. Major, pp. 147 158. GSA Special Papers Vol. 375. Geological Society of America, Boulder, Colorado.

Torrence, Robin

2019 Social Responses to Volcanic Eruptions: A Review of Key Concepts. Quaternary International 499:258-265.

Yagi, Hiroaki, Shione Shibata, and Liuba Moran

2015 La cerámica de El Cambio, Valle de Zapotitán, El Salvador. In XXVIII Simposio de Investigaciones Arqueológicas en Guatemala 2014, edited by Bárbara Arroyo, Luis Méndez Salinas, and Lorena Paiz, pp. 855-863. Museo Nacional de Arqueología y Etnología, Guatemala City.

Submitted August 17, 2020; Revised January 27, 2021; Accepted February 25, 2021 